\title{
An Evaluation of Hepatitis B Virus and Hepatitis C Virus Frequency and the Anti-hepatitis $B$ Surface Seropositivity of Syrian Refugees in the Karabük Province
}

\author{
Karabük Ilindeki Suriyeli Sığınmacılarda Hepatit B Virüs, Hepatit C Virüs Sıklığının ve \\ Anti-hepatit B Yüzey Seropozitifliğinin Araștırılması
}

\author{
(1) Nergis Aşgın, (1) Şerife Satılmış \\ Karabük University Training and Research Hospital, Clinic of Medical Microbiology, Karabük, Turkey
}

\begin{abstract}
Objectives: To investigate the frequency of hepatitis B Virus (HBV) and HCV with anti- hepatitis B Surface (HBs) seropositivity using serological and molecular methods in Syrian refugees in the Karabük. Materials and Methods: The study included the HBs Antigen (HBsAg), anti-HBs, anti-HCV, HCV-RNA, HBV-DNA, and HCV genotyping results of Syrian refugees who presented at the Karabük University Training and Research Hospital between January 2016 and March 2019

Results: The 809 patients were comprised of 536 (66.3\%) females and $273(33.7 \%)$ males with a mean age of 34 years. HBsAg was found to be positive in $2.3 \%$ of patients and in all HBV-DNA were positive. The anti-HBs seropositivity rate was determined as $21.6 \%$ and a significant difference was determined between age groups $(p=0.001)$. The anti-HCV was positive in $8(1 \%)$ patients and the HCV-RNA viral load was determined in $7 / 8$. In these 7 patients, the HCV genotype was determined as genotype $1 \mathrm{~b}$ in 3, genotype 3 in 2 , and genotype 4 in 2 .

Conclusion: This study showed that while the frequency of HBV and HCV in Syrian refugees was similar to the data for Turkey, anti-HBs seropositivity was extremely low. Hepatitis B vaccination programs for Syrian refugees should be implemented and regularly followed up.

Keywords: Syria, hepatitis, virus
\end{abstract}

$0 ̈ Z$

Amaç: Bu çalışmada amacımız Karabük ilindeki Suriyeli sığınmacılarda serolojik ve moleküler yöntemlerle hepatit B Virüs (HBV) ve HCV sıklığı ile anti-hepatit B yüzey (HBs) seropozitifliğini araştırmaktır.

Gereç ve Yöntemler: Bu çalışmaya Ocak 2016-Mart 2019 tarihleri arasında Karabük Üniversitesi Eğitim ve Araştırma Hastanesi'ne başvuran toplam 809 Suriyeli sığınmacının HBs antijen (HBsAg), anti-HBs, anti-HCV, HCV-RNA, HBV-DNA ve HCV genotipleme sonuçları dahil edildi.

Bulgular: Toplam 809 hastanın 536'sı $(\% 66,3)$ kadın, 273'ü $(\% 33,7)$ erkekti. Hastaların yaș ortalaması 34 idi. Hastaların \%2,3'ünde HBsAg pozitif bulundu ve bunların tümünde HBV-DNA pozitif idi. Anti-HBs seropozitiflik oranı ise \%21,6 olup, yaş grupları arasında anlamlı farkllık gözlendi $(p=0,001)$. Anti-HCV, hastaların \%1'inde $(n=8)$ pozitifti. Anti-HCV pozitif sekiz hastanın 7'sinde HCV-RNA viral yük saptandı. Yedi hastanın 3'ü HCV genotip 1b, 2'si genotip 3 ve 2 'si de genotip 4 olarak tiplendirildi.

Sonuç: Bu çalışmada Suriyeli sığınmacılarda HBV ve HCV sıklığı Türkiye verilerine benzer oranlarda iken, anti-HBs seropozitifliği oldukça düşük bulunmuştur. Suriyeli sığınmacılara yönelik hepatit B aşılama programları düzenli olarak takip edilmelidir.

Anahtar Kelimeler: Suriye, hepatit, virüs

Aşgın N, Satılmış Ş. An Evaluation of Hepatitis B Virus and Hepatitis C Virus Frequency and the Anti-hepatitis B Surface Seropositivity of Syrian Refugees in the Karabük Province. Viral Hepat J. 2019;25:84-87. 


\section{Introduction}

The 2011 outbreak of civil war in Syria led to the greatest refugee crisis since World War II, with 4.8 million of Syrians fleeing to neighboring countries, which included Egypt, Jordan, Lebanon, Turkey and Iran. In September 2019, it was reported that there are 3.658 million Syrian refugees in Turkey. This has led to various health problems, one of which is viral hepatitis $(1,2)$. Viral hepatitis can lead to severe health problems such as cirrhosis of the liver and hepatocellular carcinoma $(\mathrm{HCC})(3,4)$. The hepatitis $B$ virus (HBV) and hepatitis $\mathrm{C}$ virus ( $\mathrm{HCV}$ ) are transmitted sexually and from infected mothers to newborns vertically, through parenteral contact with infected blood and body fluids (5).

HBV is the most common cause of chronic viral hepatitis worldwide. Approximately 250 million people throughout the world are infected with chronic HBV and it is estimated that on average 887.000 die each year due to cirrhosis or HCC (6). Vaccination against HBV is the most effective method of protection. In 1998, hepatitis $B$ vaccination was included in the national vaccination program in Turkey, and from that time, has been administered in three doses. In Syria, a three-dose vaccination for HBV has been recommended since 1993 and the vaccination rates, especially in young people, increased (7). However, vaccination programs cannot be fully implemented due to the civil war in Syria.

A vaccine for HCV has not yet been developed. More than 71 million people worldwide are infected with $\mathrm{HCV}$, and it is estimated that 399.000 deaths per year are due to $\mathrm{HCV}$ infection-related cirrhosis or liver cancer (8). The prevalence of $\mathrm{HCV}$ has been reported as $<1 \%$ in Syria (9).

The aim of this study was to investigate the frequency of HBV and $\mathrm{HCV}$ and anti-hepatitis B surface antigen (HBsAg) seropositivity using serological and molecular methods in Syrian refugees in the Karabük province of the western Black Sea region of Turkey.

\section{Materials and Methods}

This study was approved by the Non-invasive Clinical Research Ethics Board of Karabük University (approval number: 77192459050.99-E.41215). The study included the HBsAg, anti-HBs, antiHCV, HCV-RNA, HBV-DNA and HCV genotyping results of 809 Syrian refugees who were admitted at the Karabük University Training and Research Hospital between January 2016 and March 2019. Results of repetitive patient results were excluded from the study and the first serological parameters of each patient were evaluated.

The patients were separated into 4 age groups of 0-20 years, 21-40 years, $41-60$ years, and $61+$ years. The test results of patients were obtained from the hospital laboratory information system.

In the serum samples sent to the microbiology Laboratory, the HBsAg, anti-HBs, and anti-HCV tests were performed using the chemiluminescence method with the ARCHITECT i2000 SR device (Abbott Diagnostics, USA). For HBV-DNA and HCV-RNA, first viral nucleic acid isolation was performed by the quantitative polymerase chain reaction (qPCR) method with a Magnesia 16 device (Anatolia Genework, Turkey). Then, the HBV-DNA and HCV-RNA quantitative tests were performed using the qPCR method with a Montania 4896 device (Anatolia Genework, Turkey) according to the manufacturer's instructions. In HCV-RNA positive patients, the Bosphore HCV genotype kit (Anatolia Geneworks, Turkey) was used to determine 8 different genotypes of HCV (1, $1 \mathrm{a}, 1 \mathrm{~b}, 2,3,4,5$, and 6). The HCV genotyping test was also applied using the qPCR method with the Montania 4896 device.

\section{Statistical Analysis}

The data obtained in the study were analyzed statistically using SPSS version 22.0 software (SPSS Inc, Armonk, NY, USA). Conformity of the data to normal distribution was assessed using the Kolmogorov-Smirnov test. Descriptive statistics were stated as number $(\mathrm{n})$, percentage (\%) and median values. For group comparisons, the Pearson's chi-square test was used. A value of $\mathrm{p}<0.05$ was accepted as statistically significant.

\section{Results}

The 809 patients were comprised of 536 (66.3\%) females and $273(33.7 \%)$ males with a mean age of 34 years (range: 2-94 years). The presence of HBsAg was detected in 19 (2.3\%) patients, 10 females and 9 males. In all the HBsAg positive patients HBV-DNA viral load was detected. Anti-HBs seropositivity was determined in 175 (21.6\%) patients and a significant difference was determined between age groups in respect to this parameter $(p=0.001)$ (Table 1).

No significant relationship was determined between the genders in respect to HBsAg and anti-HBs seropositivity $(p=0.200)$. Of the 10 female HBsAg positive patients, eight were of childbearing age (15-49 years). Anti-HCV was positive in 8 (1\%) patients, with HCV-RNA positivity determined in 7. In these 7 patients, the HCV genotype was determined as genotype $1 \mathrm{~b}$ in 3 , genotype 3 in 2, and genotype 4 in 2. The distribution of the serological parameters according to age and gender were shown in Table 2.

\section{Discussion}

Chronic hepatitis B is a global health threat causing high rates of mortality and morbidity. Of patients, $20 \%-40 \%$ are at risk of developing cirrhosis and HCC. Based on the HBV carrier rate, the world can be divided into 3 regions of high, medium, and low endemicity. Turkey is a middle endemic country (2\%-8\%) for HBV with a prevalence of $2.3 \%(10,11)$. Vaccination coverage has increased in Turkey in recent years with vaccination rates increasing from $64 \%$ in 1999 to $98 \%$ in 2016 (12). While the vaccination rate in Syria was $83 \%$ in 2008, it has fallen to $69 \%$ due to the outbreak of war $(5,7)$. Also, Syria is one of the middle endemic countries

\begin{tabular}{|l|l|l|}
\hline \multicolumn{3}{|l|}{ Table 1. Distribution of anti-HBs results between age groups } \\
\hline Age & Anti-HBs negative $\mathbf{n}(\%)$ & Anti-HBs positive $\mathbf{n}(\%)$ \\
\hline $0-20$ years & $62(62.6)$ & $37(37.4)$ \\
\hline $21-40$ years & $387(80.8)$ & $92(19.2)$ \\
\hline $41-60$ years & $130(80.2)$ & $32(19.8)$ \\
\hline$>61$ years & $55(79.7)$ & $14(20.3)$ \\
\hline Total & $634(78.4)$ & $175(21.6)$ \\
\hline HBs: Hepatitis B surface & \\
\hline
\end{tabular}


Table 2. The distribution of the serological parameters of Syrian patients according to age and gender

\begin{tabular}{|c|c|c|c|c|c|c|c|}
\hline & & \multicolumn{2}{|c|}{ HBsAg } & \multicolumn{2}{|c|}{ Anti-HBs } & \multicolumn{2}{|c|}{ Anti-HCV } \\
\hline & & $\%$ & n & $\%$ & n & $\%$ & $\mathrm{n}$ \\
\hline Gender & Female $(n=536)$ & 10 & 0.02 & 116 & 21.6 & 5 & 0.009 \\
\hline \multirow{3}{*}{ Age groups } & $0-20(n=99)$ & 2 & 0.02 & 37 & 37.3 & - & - \\
\hline & $21-40(n=479)$ & 12 & 0.02 & 92 & 19.2 & 1 & 0.002 \\
\hline & $>61(n=69)$ & 2 & 0.03 & 14 & 20.2 & 3 & 0.04 \\
\hline
\end{tabular}

for HBV (13). The results of this study showed that while the rate of anti-HBs seropositivity in Syrian patients in our region was extremely low at $21.6 \%$, HBsAg positivity was determined as $2.3 \%$. All these patients were diagnosed with chronic viral hepatitis and an HBV-DNA viral load was detected in all.

In the current study, HBsAg positivity was not found at a high rate. However, eight of ten HBsAg positive female patients were in the child-bearing age group. Inci et al. (14) also reported HBsAg positivity as $1.1 \%$ in 2158 Syrian pregnant women. This constitutes a threat to newborns. The risk of an infant acquiring HBV perinatally from an infected mother is 70\%-90\%. Therefore active and passive HBV immunoprophylaxis is crucial.

In a study of 140 Syrian children, Köse et al. (5) reported HBsAg positivity at a higher rate (4.2\%) than the data for Turkey and antiHBs seropositivity was determined at a rate of 52.8. This was attributed to Syrian children generally living in poor socio-economic conditions and no follow up vaccinations. In the current study, anti-HBs positivity was found to be $37.4 \%$ in the age group $<20$ years. This rate was higher than that of the other age groups and similar to findings in other studies, indicating that vaccinations were insufficient.

$\mathrm{HCV}$ is another important pathogen that leads to viral hepatitis and hepatitis $\mathrm{C}$ infections becoming chronic at a rate of $85 \%$. To date, no vaccination has been developed for HCV. In Turkey, the prevalence of $\mathrm{HCV}$ has been reported as $1.6 \%(5,15)$ and according to Centers for Disease Control and Prevention data, the $\mathrm{HCV}$ prevalence in the Syrian population is estimated to be $0.4 \%$ (16). The results of this study showed anti-HCV seropositivity in Syrian refugees at a similar rate $(1 \%)$ to the data for Turkey. In addition to the detection of HCV RNA in anti-HCV positive patients, it is also necessary to identify the HCV genotype to determine the treatment protocol and duration of treatment (17). The most common HCV genotype is genotype 1 worldwide, followed by genotype 3 . Studies have reported genotype $1 \mathrm{~b}$ to be the most frequently seen in Turkey $(60 \%-100 \%)(18,19,20)$. However, in a 2015 study by Caliskan et al. (21) of 313 HCV-RNA positive patients, genotype 3 was found at a rate of $46 \%$. This high rate was attributed to the study group being composed of refugees, drug addicts, and prisoners. In Syria, the predominant genotype is genotype $4(22,23)$. In the current study, of the seven Syrian refugees found to be HCV-RNA positive, three were determined as genotype 1 b, 2 as genotype 3, and 2 as genotype 4, which was similar to the data for Turkey.

\section{Conclusion}

Although the results of the current study did not show a high rate of HBV and HCV prevalence in Syrian patients, anti-HBs seropositivity was found to be extremely low.

This indicates that hepatitis $B$ vaccination is not adequate among the Syrian people. Therefore, hepatitis B vaccination programs for Syrian refugees must be followed up regularly. Furthermore, as the majority of $\mathrm{HBsAg}$-positive females were in the child-bearing age group, this constitutes a risk for hepatitis B infection in newborn infants. Pregnant women must be screened for HBV and for those found to be positive, active, and passive immunoprophylaxis must be applied to the infant in the perinatal period.

\section{Acknowledgements}

We thank to Scribendi services for editing the manuscript.

\section{Ethics}

Ethics Committee Approval: This study was approved by the Non-invasive Clinical Research Ethics Board of Karabük University (approval number: 77192459-050.99-E.41215).

Informed Consent: Retrospective study.

Peer-review: Externally peer-reviewed.

\section{Authorship Contributions}

Concept: N.A., Ş.S., Design: N.A., S..S., Data Collection or Processing: N.A., S..S., Analysis or Interpretation: N.A., Ş.S., Literature Search: N.A., S..S., Writing: N.A., Ş.S.

Conflict of Interest: The authors declare no conflict of interest.

Financial Disclosure: The authors declare that this study has not received any financial support.

\section{References}

1. Nimer NA. A Review on Emerging and Reemerging of Infectious diseases in Jordan: the aftermath of the Syrian crises. Canad J Infect Dis Med Microbiol. 2018;24:8679174.

2. https://data2.unhcr.org/en/situations/syria/location/113. Registered Syrian Refugees. 2019.

3. Aygen B, Günal Ö, Yıldız O, Celen MK, Akhan S, Barut Ş, Ayaz C. Hepatitis B virus and hepatitis C virus Co-infection: An Evaluation of Eighty-Two Patients. J Viral Hepat. 2017;23:14-19.

4. Kizilates F, Berk H, Coban M, Seyman D, Sarikaya AM, Sari F Oztoprak N. Seroprevalence of hepatitis B and C virus in patients who undergo hemodialysis in Antalya province, Turkey. Asian Biomedicine. 2016;10(4):339-344. 
5. Köse S, Ödemiş I, Çelik D, Gireniz Tatar B, Akbulut I, Çiftdoğan DY Hepatitis A, B, C and HIV seroprevalence among Syrian refugee children admitted to outpatient clinics. Infez Med. 2017;25:339343.

6. World Health Organization. Global hepatitis report 2017. World Health Organization. 2017. https://www.who.int/news-room/factsheets/detail/hepatitis-b.

7. Bashour H, Muhjazi G. Hepatitis B and C in the Syrian Arab Republic: A review. Eastern Mediterranean Health Journal. 2016;22:267273.

8. World Health Organization. Global hepatitis report 2017. World Health Organization. 2017. https://www.who.int/news-room/factsheets/detail/hepatitis-c.

9. Chemaitelly H, Chaabna K, Abu-Raddad LJ. The epidemiology of hepatitis $\mathrm{C}$ virus in the fertile crescent: Systematic review and meta-analysis. PloS One. 2015;10:e0135281.

10. Ozkan H. HBV treatment in Turkey: The value of hepatitis B surface antigen quantification of chronic hepatitis B patients in the long-term follow-up-a single-center study. Euroasian $\mathrm{J}$ Hepatogastroenterol. 2017;7:82-83.

11. Ahmad I, Ahmad K, Taseer IH, Ahmad W, Faroogi JI, Ullah O. Frequency of hepatitis $B$ envelope antigen-negative chronic hepatitis B virus infection in untreated patients from three cities in Pakistan. Asian Biomedicine. 2017;11:73-79.

12. https://hsgm.health.gov.tr/infectious disease/Turkey viral hepatitis prevention and control program. 2017. (Turkish).

13. Antaki N, Haffar S, Ali Deeb S, Assaad F, Abou Harb R, Zeibane N, Nasserelddine M, Ibrahim N, Alhaj N, Jabbour E, Aaraj R, Antaki F, Kebbewar K, Syrian Working Group for the Study of Viral Hepatitis. High prevalence of HBV genotype D in Syria and the clinical characteristics of hepatitis $B$ e antigen-negative chronic hepatitis B. Epidemiol Infect. 2010;138:40-44.

14. Inci A, Yıldırım D, Seçkin KD, Gedikbaşı A. Analysis of HbsAg positivity rate before and after vaccination in Turkish and Syrian refugee pregnant women. J Infect Dev Ctries. 2017;11:815-818.
15. Celdir MG, Kara IA, Coşkuner SB, Keskin B, Küçüker M, Orer HS, Ergönül $\mathrm{O}$. Hepatitis $\mathrm{C}$ prevalence in Turkey: Estimation through meta-analysis. Eur J Pub Heal. 2014;24:168-169.

16. https://www.cdc.gov/immigrantrefugeehealth/pdf/syrian-healthprofile.pdf. 2016.

17. Ozer Etik D, Ocal S, Boyacioglu AS. Hepatitis C infection in hemodialysis patients: A review. World J Hepatol. 2015;7:885895.

18. Kirişci O,Çalışkan A. The predominance of genotype 3 in hepatitis C virus in the province of Kahramanmaras, Turkey/Genotype Distribution of Syrian Refugee Patients with hepatitis C in Kahramanmaras Province. Jundishapur Journal of Microbiology. 2019;12:e80872.

19. Yıldız Kaya S, Mete B, Kaya A, Balkan II, Saltoğlu N, Tabak F. Evaluation of chronic hepatitis $\mathrm{C}$ patients from different aspects before the use of direct acting antivirals. Viral Hepat J. 2017;23:69.

20. Tiryaki Y, Çetin Duran A, Özçolpan O. Distribution of hepatitis C virus genotypes in Aydın Province. Viral Hepat J. 2018;24:70-74

21. Caliskan A, Kirisci O, Ozkaya E, Ozden S, Tumer S, Caglar S, Guler S, Senol H. Distribution and predominance of genotype 3 in hepatitis $\mathrm{C}$ virus carriers in the province of Kahramanmaras, Turkey. Hepat Mon. 2015;15:25142.

22. Ghaderi-Zefrehi H, Gholami-Fesharaki M, Sharafi H, Sadeghi F, Alavian SM. The Distribution of Hepatitis C Virus Genotypes in Middle Eastern Countries: A Systematic Review and MetaAnalysis. Hepat Mon. 2016;16:e40357.

23. Cirit OS, Uzala Mızraklı A, Vurupalmaz $Y$, Gümüş $H H$, Özturhan $H$, Barış A. Genotyping distribution of hepatitis $C$ virus in Şanliurfa province and effect of syrian patients. Viral Hepat J. 2019;25:6266. 